\title{
Solid State Fermentation of Bee-Collected Pollen
}

\author{
Dhananjay V. Shirsat*, Snehal K. Kad and Dhananjay M. Wakhle \\ Centre of Excellence in Apicultural Biotechnology, Vidyapratisthan's School of \\ Biotechnology, Baramati, Maharashtra, India \\ *Corresponding author
}

\section{A B S T R A C T}

\section{Keywords}

Solid state

fermentation, Pollen fermentation, LAB,

Bee-pollen, Apis mellifera

Article Info

Accepted:

15 April 2019

Available Online:

10 May 2019
This research work aimed at obtaining a novel natural food product from pollen, safe and improved nutritional value, to be used as a dietary supplement or a functional ingredient for formulating other foods. Bee-collected pollen subjected to lactic acid fermentation using lactic acid bacteria Lactobacillus lactis and its effect on some of the natural characteristics of the pollen were studied. The optimum conditions for the pollen fermentation were provided that are, anaerobic condition for solid state fermentation at $35^{\circ} \mathrm{C}$ for first 96 hours, then $20^{\circ} \mathrm{C}$ for next 72 hours, and optimum moisture content was $35-40 \%$. The process was characterized byt the production of lactic acid and decrease in $\mathrm{pH}$ and sugar content. As a result of this project the proteins were increased by $1.53 \%$, total sugars were decreased by $32.6 \%$, lactic acid content increased by $1.35 \%$, total free amino acid content increased by $1.99 \%$, total poly-phenol content decreased by $1.8 \%$, increment in all minerals and radical scavenging activity increased by $18.86 \%$ fermented pollen. The solid state fermentation of the bee pollen by Lactic acid bacteria were effective to increase its nutritional value.

\section{Introduction}

Pollen exists for a time as an independent unit and thus contains most nutrients, essential for life. Man has long been the consumer of pollen and pollen containing food. In many living organisms like insects, pollen is essential for their life cycle, being rich particularly in protein (Wakhle, 1981). Once bee pollen was defined in legislation as food, the nutritional value of this product became important. It contents high concentration of reducing sugars, essential amino acids, fatty acids, minerals and abundant in proteins and vitamins (Campos et al., 2010).
The bee pollen is used as a nutritional source for human from ancient times, but the pollen wall structure resists the digestion and decay, so they remain intact in digestive tracks of the animals and the pollen contents will not be released in the digestive tract ( $T$ 'aiand Cane, 2000). So it is suggested that to increase the digestibility and palatability of pollen it should be treated with chemicals or acids to loosen the pollen wall.

It is well known that honey bees do not consume pollen directly. They store it in combs by adding their saliva containing lactic acid bacteria. The lactic acid bacteria have 
found in the honey stomach (Olofssonet al., 2011). This pollen then undergoes the lactic acid fermentation. The lactic acid fermentation increases shelf life, improve palatability, digestibility and nutritional value (Gilliam, 1997).

\section{Materials and Methods}

\section{Sample collection}

Pollen collected from Apismellifera bee hives located in the area of Jalgoan Village of Pune district of Maharashtra. (N $18023.275^{\prime}$ and E 07502.592 ') where the hive was used for pollination of Sunflower (Helianthus anпииs) crop. Pollen was collected using a pollen trap by attaching to the entrance of the hive. The culture of lactic acid bacteria Lactobacillus lactis was collected from Vidyapratisthan School of Biotechnology-Culture Collection laboratory, Baramati.

\section{Solid state fermentation}

Pure culture of lactic acid bacteria Lactobacillus lactis, $20 \mathrm{ml}$ were inoculated in $100 \mathrm{~g}$ of bee-collected pollen in a sterile glass jar, under aseptic condition. It was incubated at $35^{\circ} \mathrm{C}$ temperature for the first 96 hours, then $20^{\circ} \mathrm{C}$ for next 72 hours under anaerobic conditions. After the fermentation process, the product was stored at $4^{0} \mathrm{C}$ to avoid nutrient losses and spoilage. The process of fermentation was monitored by estimating an increase in lactic acid content and a decrease in $\mathrm{pH}$.

\section{Determination of moisture content in pollen}

The moisture content of pollen was determined by the method described in AOAC, (1997). The $1.5 \mathrm{~g}$ pollen sample heated in a hot air oven at $130^{\circ} \mathrm{C}$ until the constant weight of pollen obtained.

\section{Estimation of total acidity in pollen}

Total acidity was estimated by acid-base titration with $0.1 \mathrm{~N}$ Sodium hydroxide and phenolphthalein as an indicator (AOAC, 1990). The acidity was determined by the following formula

Percent of Lactic acid $=\frac{\mathrm{ml} \text { of NaOH used } \mathrm{x} \text { Conc. of } \mathrm{NaOH} \times 0.090}{\text { Weight of sample }}$

Where 0.090 is an equivalent weight of Lactic acid.

\section{Estimation of protein content in pollen}

Protein content was estimated by Folin-Lowry method (Lowryet al., 1951) the $0.2 \mathrm{ml}$ sample were allowed to react with $2 \mathrm{ml}$ alkaline copper sulfate solution followed by $10 \mathrm{~min}$ incubation at $37^{\circ} \mathrm{C}$ then added $0.2 \mathrm{ml}$ of Folin-Ciocalteau phenol reagent for $10 \mathrm{~min}$ at $37^{\circ} \mathrm{C}$ and the absorbance was read at $660 \mathrm{~nm}$ using Spectrophotometer (JASCO 630). Bovine serum albumin was taken as a standard protein. The value of total protein expressed as $\mathrm{mg} / \mathrm{g}$ of pollen.

\section{Total sugar content estimation in pollen}

The total sugar content was estimated by the Anthrone method (Hedge et al.,1962) with some modifications. The $100 \mathrm{mg}$ pollen sample washydrolyzed in $5 \mathrm{ml} 2.5 \mathrm{~N} \mathrm{HCl}$ in boiling water bath for 3 hours followed by cooling neutralized with solid sodium carbonate and volume make up to $100 \mathrm{ml}$. the $1 \mathrm{ml}$ prepared sample was allowed to react with $2 \mathrm{ml}$ anthrone reagent prepared in 75\% $\mathrm{H}_{2} \mathrm{SO}_{4}$. The absorbance was taken at $630 \mathrm{~nm}$ using Spectrophotometer (JASCO 630). And from the standard curve, the concentration of sugar was estimated. Glucose was taken as a standard. 
Quantitative determination of total free amino acids

Free amino acid extraction and quantitative estimation of pollen sample performed by the method given by Sadasivam and Manickam (1992). 500mg of pollen sample mixed with $10 \mathrm{ml} 80 \%$ ethanol and homogenized. Then centrifuge and collect the supernatant. Repeat method twice with residue. Evaporate ethanol by using a boiling water bath and dissolve the residue in distilled water. Take $2 \mathrm{ml}$ of this sample and add $1 \mathrm{ml}$ Acetone- Ninhydrin reagent $(0.1 \%$ Ninhydrin in acetone) then incubate it in boiling water bath for $20 \mathrm{~min}$ followed by cooling under running tap water. And take absorbance at 570nm. Express the free amino acid content in pollen protein in terms of $\mathrm{mg}$ of glycine equivalent per gram of pollen.

\section{Estimation of total poly-phenol content in pollen}

The $1 \mathrm{~g}$ pollen sample homogenized and extracted using methanol: water $(1: 1 \mathrm{v} / \mathrm{v})$ as an extraction solvent. The solvent was evaporated at $60^{\circ} \mathrm{C}$ for 4 hours. Dissolve extract in sterile distilled water and store in the refrigerator. The $0.5 \mathrm{ml}$ of a prepared sample taken and add $2.5 \mathrm{ml}$ of $1 \mathrm{~N}$ FolinCiocalteau reagent followed by $0.5 \mathrm{ml} 4 \%$ $\mathrm{Na}_{2} \mathrm{CO}_{3}$. Take gallic acid as a standard and absorbance were read at $750 \mathrm{~nm}$ using Spectrophotometer (JASCO 530).

\section{Determination of radical scavenging activity of pollen}

For ABTS [2,2'- azinobis (3-ethylebenzothiazoline-6- sulfonic acid)] assay, the procedure followed the method of Arnaoet al.,(2001). The stock solutions included $7 \mathrm{mM}$ ABTS solution and $2.4 \mathrm{mM}$ potassium persulphate solution. The working solution was then prepared by mixing the two stock solutions in equal quantities and allowing them to react for 14 hours at room temperature in the dark. The solution was then diluted by mixing $2 \mathrm{~mL}$ ABTS solution with $50 \mathrm{~mL}$ methanol. The ethanolic pollen extract used for determining the antioxidant activity were prepared by extracting $1 \mathrm{~g}$ of crushed pollen in $15 \mathrm{ml}$ of $70 \%$ ethanol in a water bath at $70^{\circ} \mathrm{C}$ for $30 \mathrm{~min}$. the next sample was centrifuged and the supernatant was stored at $4^{0} \mathrm{C}$ in the refrigerator. The ethanolic pollen extract $1 \mathrm{ml}$ were allowed to react with $2 \mathrm{ml}$ of the ABTS solution and the absorbance was then taken at $734 \mathrm{~nm}$ after $5 \mathrm{~min}$. incubation.

The ABTS scavenging capacity of the compound was calculated as,

\section{ABTS radical scavenging activity (\%)}

$$
=\frac{\text { Absorbance of control }- \text { Absorbance of sample }}{\text { Absorbance of control } x 100}
$$

Where Absorbance of control is the absorbance of ABTS radical in methanol; Absorbance of sample is the absorbance of an ABTS radical solution mixed with the sample.

\section{Determination of mineral content of the pollen}

The minerals $\mathrm{Ca}, \mathrm{Cu}, \mathrm{Mn}, \mathrm{Mg}, \mathrm{Fe}, \mathrm{Zn}$ were determined after the incarnation of $1 \mathrm{~g}$ pollen at $555^{\circ} \mathrm{C}$ in Muffle furnace, until a constant weight was obtained. Next, the ash was solubilized in $25 \mathrm{ml}$ of $\mathrm{HNO}_{3} 50 \%$, heated in a water bath for $30 \mathrm{~min}$, filtered and the minerals determined by Atomic Absorption Spectrophotometer (AAS) (Parkin-Elmar Analyst 200).

\section{Results and Discussion}

In the fermentation process the lactic acid produced by the microbial actions. The lactic acid bacterium utilizes the carbohydrates present in the pollen and produces the lactic 
acid. The lactic acid content after 168 hrs fermentation was $6.10 \%$ in fermented pollen respectively while as in control set the acid content remains constant. The lactic acid content slightly increased after fermentation of the bee-collected pollen. The Gilliam (1997) has been reported 115 fold increase in titratable acidity in stored pollen load by bees. The increase in acidity indicates active fermentation process. Carloset al.,(2012) reported high acid production up-to 400 meq $/ \mathrm{kg}$ in the fermentation of bee pollen by different probiotic starters he also reported eventually decrease in the sugar content of the pollen. In pollen fermentation process the total sugar content has found decreased eventually. In fermented pollen, it was decreased by $31.60 \%$ within 168 hrs of the fermentation process.

The pollen contains various sugars like glucose, fructose and minute amount of sucrose. But after fermentation the sugars concentration get changes (Table 1). Stanciu et al., (2011) reported 52.16\% fructose in bee pollen and $57.51 \%$ in bee bread that is naturally fermented pollen by bee stomach bacteria. The glucose was $42.59 \%$ in bee pollen and $35.88 \%$ bee bread, the sucrose accounted for $1.57 \%$ and $0.12 \%$ in bee pollen and bee bread respectively. The total sugar content in pollen was reported $40 \%$ by Campos et al., (2008). Because of the increase in the acidity, the $\mathrm{pH}$ of the bee pollen was decreased. As per the reports of De-Grandi-Hoffman et al., (2013) naturally the $\mathrm{pH}$ of the pollen is 5.5-6.5. It varies by botanical source. The $\mathrm{pH}$ of the bee bread ranges between 3.5 and 4.5. The fermentation found successful to decrease $\mathrm{pH}$ up to 4.2 in fermented pollen. These $\mathrm{pH}$ ranges are effective to avoid the growth of nonessential microorganisms in pollen. So it will effective to increase the shelf life of the final product. It will also improve palatability, digestibility and nutritional value (Gilliam, 1997) (Fig. 1).
The water content in the dried pollen was reported $6-8 \%$ by Camposet al.(2008). In the fresh bee-collected pollen ranges from 20-30 $\%$ (Campos et al., 2010). The high water content required for the microbial action in pollen for fermentation. The moisture content of the pollen will vary plant to plant, region by region and seasonal variations also found in bee pollen, it will range from 14-30\%, but for fermentation the amount of water is necessary is above $36 \%$ for microbial activity (Carlos et al., 2012). For solid state fermentation, the fresh pollen was collected in the cold season that having water $34 \%$.

As per the evaluation, the protein content of the Sunflower pollen collected by the bees was $26.8 \pm 0.2 \mathrm{mg} / \mathrm{g}$ and after fermentation, the protein content found increased by 12.53 $\pm 0.2 \mathrm{mg} / \mathrm{g}$. Campos et al., (2010) reported the protein content of the bee pollen ranged 10 to $40 \%$ and Stanciu et al., (2011) reported it ranges 15 to $28 \%$ and in bee bread, it was 16.94 to $30.23 \%$.

The total free amino acid content of the Helianthus annuus pollen was estimated that was $80.76 \pm 0.20 \mathrm{mg} / \mathrm{g}$. In fermented pollen, it was found increased. In fermented pollen, it was $99.95 \pm 0.13 \mathrm{mg} / \mathrm{g}$. As per Bhunia and Mondal (2012) free amino acid content in different pollen ranges between 53.5 - 68.5 $\mathrm{mg} / \mathrm{g}$. As per DeGrandi-Hoffman et al., (2013) mention, the free amino acid also can be incorporated into proteins. The amino acid content of fermented pollen or bee bread probably depends not only on the botanical source of the pollen but also on the bees and microflora added by them (Table 3 ).

The polyphenol content of the bee pollen found decreased after fermentation. It was also reported by Carpes et al., (2009). In fermented pollen, it decreased by $18 \mathrm{mg} / \mathrm{g}$. Polyphenols are responsible for radical scavenging activity or anti-oxidant activity. The free radical scavenging activity in bee 
pollen has been found $67.27 \%$, but it will increase after fermentation up to $86.06 \%$. The free radical scavenging activity was found effective in the treatment of diseases like Diabetes, cancer, hypertension (Pandey and Rizvi, 2009).

Table.1 Lactic acid and total sugar content during the fermentation process

\begin{tabular}{|l|l|l|l|l|}
\hline \multirow{2}{*}{ Time in Hours } & \multicolumn{2}{|l|}{ Lactic acid \% } & \multicolumn{2}{l|}{ Total Sugar \% } \\
\cline { 2 - 5 } & Control & Fermented Pollen & Control & Fermented Pollen \\
\hline $\mathbf{0}$ & 4.12 & 4.2 & 41.83 & 42 \\
\hline $\mathbf{2 4}$ & 4.18 & 4.23 & 41.23 & 30.8 \\
\hline $\mathbf{4 8}$ & 4.3 & 4.86 & 40.2 & 28 \\
\hline $\mathbf{7 2}$ & 4.32 & 5.49 & 39.6 & 29.6 \\
\hline $\mathbf{9 6}$ & 4.35 & 6.09 & 39 & 14.8 \\
\hline $\mathbf{1 2 0}$ & 4.35 & 6.09 & 38.7 & 12.6 \\
\hline $\mathbf{1 4 4}$ & 4.36 & 6.09 & 38.4 & 10 \\
\hline $\mathbf{1 6 8}$ & 4.36 & 6.1 & 38.5 & 10.4 \\
\hline
\end{tabular}

*Values in the table are Arithmetic mean of three replications

Table. 2 Change in nutritive value after fermentation

\begin{tabular}{|l|c|c|c|c|c|c|}
\hline \multicolumn{1}{|c|}{ Pollen } & $\begin{array}{c}\text { Moisture } \\
\text { content } \\
\%\end{array}$ & $\begin{array}{c}\text { Protein } \\
(\mathbf{m g} / \mathbf{g})\end{array}$ & $\begin{array}{c}\text { Total } \\
\text { sugar } \\
\text { content \% }\end{array}$ & $\begin{array}{c}\text { Total free } \\
\text { amino acid } \\
\text { content } \\
\mathbf{( m g / g )}\end{array}$ & $\begin{array}{c}\text { Poly-phenol } \\
\text { content } \\
\text { (mg/g) }\end{array}$ & $\begin{array}{c}\text { Radical } \\
\text { scavenging } \\
\text { activity } \\
(\boldsymbol{\%})\end{array}$ \\
\hline Control & 34.66 & 26.8 & 43 & 80.76 & 33.33 & 67.27 \\
\hline $\begin{array}{l}\text { Fermented - } \\
\text { pollen }\end{array}$ & 46.66 & 41.33 & 10.4 & 99.95 & 28.66 & 86.06 \\
\hline
\end{tabular}

*Values in the table are Arithmetic mean of three replications

Table.3 Change in mineral content after fermentation of pollen

\begin{tabular}{|c|c|c|c|c|c|c|}
\hline \multicolumn{7}{|c|}{ Minerals in Pollen $(\mathbf{m g} / \mathbf{g})$} \\
\hline Pollen type & Ca & Fe & Mg & Mn & Cu & Zn \\
\hline Control & 0.154 & 0.116 & 7.032 & 0.017 & 0.003 & 0.171 \\
\hline Fermented pollen & 0.362 & 0.96 & 9.403 & 0.205 & 0.071 & 1.032 \\
\hline
\end{tabular}

*Values in the table are Arithmetic mean of three replications 
Figure.1 Change in $\mathrm{pH}$ during the fermentation process

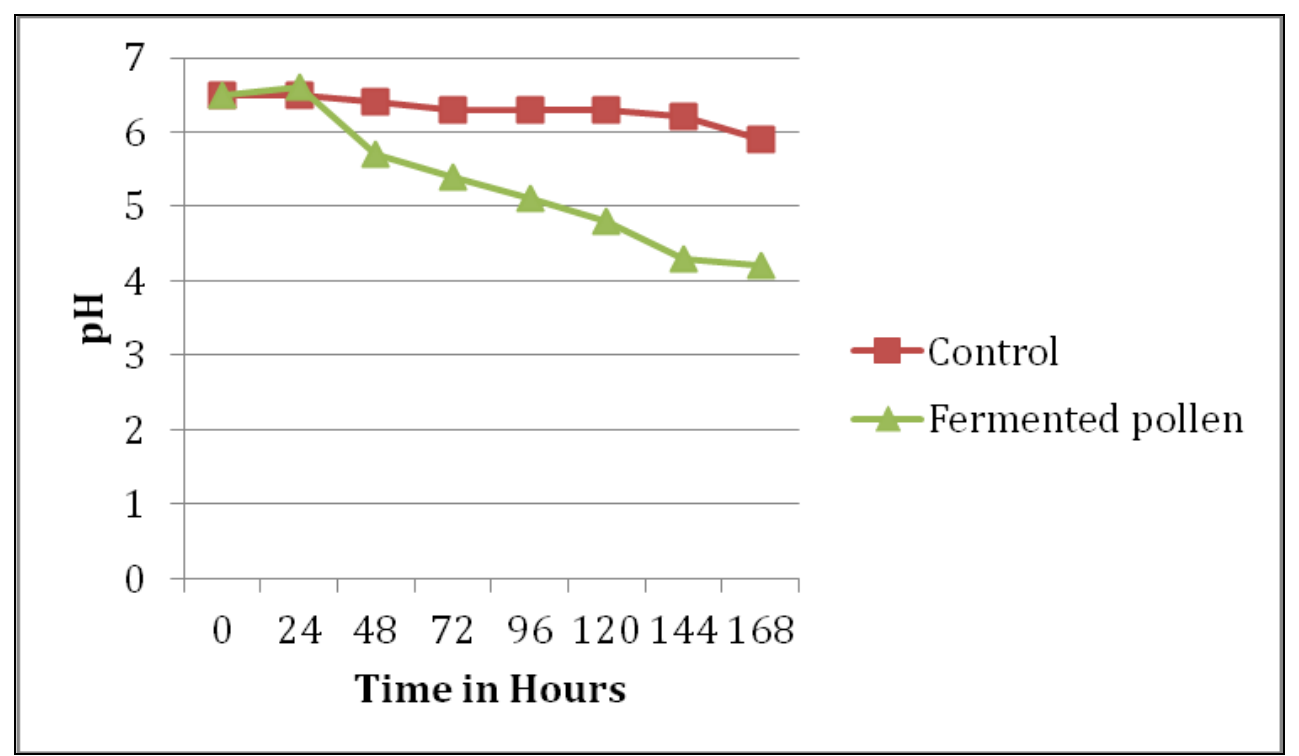

The pollen also contains the essential minerals the predominant minerals of the pollen are Phosphorous followed by potassium, calcium, and magnesium (Carpeset al., 2009). In sunflower pollen, the amount of the minerals found to be dominant are magnesium followed by calcium, iron, and zinc. The lower amount of manganese and copper. The phosphorous and potassium are not tested in the pollen samples. The amount of all minerals found increased slightly in fermented pollen then the control (Table 3).

In conclusion, the solid-state fermentation of the bee collected pollen was performed successfully at the $35^{\circ} \mathrm{C}$ temperature for 4 days followed by $20^{\circ} \mathrm{C}$ for next 4 days. The fermentation process was characterized by estimating lactic acid production, decrease in sugar content and $\mathrm{pH}$. As per the results and observation, it is suggested that the pure culture of the lactic acid bacteria, Lactobacillus lactis was found an effective starter for the solid-state fermentation of the bee collected pollen to increase its nutritive value.

\section{References}

AOAC (Association of Official Analytical Chemists), 1990. Official methods of analysis. Assoc Anal Chem.

AOAC (Association of Official Analytical Chemists), 1997. Official methods of analysis. Assoc Anal Chem.

Arnao, M.B., Cano, A., and Acosta, M., 2001. The hydrophilic and lipophilic contribution to total antioxidant activity. Food Chemistry, 73(2), pp.239244.

Bhunia, D. and Mondal, A.K., 2012. Studies on production, morphology and free amino acids of pollen of four members in the genus Nymphaea L. (Nymphaeaceae). International Journal on Science and Nature, 3(3), pp.705718.

Campos, M.G., Bogdanov, S., de AlmeidaMuradian, L.B., Szczesna, T., Mancebo, Y., Frigerio, C. and Ferreira, F., 2008. Pollen composition and standardization of analytical methods. Journal of 
Apicultural Research,47(2), pp.154161.

Campos, M.G.R., Frigerio, C., Lopes, J. and Bogdanov, S., 2010. What is the future of Bee-Pollen? Journal of ApiProduct and ApiMedical Science, 2(4), pp.131144.

Carlos, B., Amanda, M.,Carlos D. and Martha Q., 2012. Solid State Fermentation of Bee-collected pollen Induced by Lactic acid Starter Cultures with probiotic bacteria, II International Symposium On bee products, Annual meeting of the International Honey commission, 1-30.

Carpes, S.T., Mourão, G.B., De Alencar, S.M. and Masson, M.L., 2009. Chemical composition and free radical scavenging activity of Apismellifera bee pollen from Southern Brazil. Brazilian Journal of Food Technology, 12(1/4), pp.220229.

DeGrandi-Hoffman, G., Eckholm, B.J. and Huang, M.H., 2013. A comparison of bee bread made by Africanized and European honey bees (Apis mellifera) and its effects on hemolymph protein titers. Apidologie, 44(1), pp.52-63.

Gilliam, M., 1997. Identification and roles of non-pathogenic microflora associated with honey bees. FEMS microbiology letters, 155(1), pp.1-10.

Hedge, J.E., Hofreiter, B.T. and Whistler, R.L., $1962 . \quad$ Carbohydrate chemistry. Academic Press, New York, p.17.
Lowry, O.H., Rosebrough, N.J., Farr, A.L. and Randall, R.J., 1951. Protein measurement with the Folin phenol reagent. Journal of biological chemistry, 193, pp.265-275.

Olofsson, T.C., Vásquez, A., Sammataro, D. and Macharia, J., 2011. A scientific note on the lactic acid bacterial flora within the honeybee subspecies Apis mellifera (Buckfast), A. m. scutellata, A. m. mellifera, and $A . \quad m$. monticola. Apidologie, 42(6), pp.696699.

Pandey, K.B. and Rizvi, S.I., 2009. Plant polyphenols as dietary antioxidants in human health and disease. Oxidative medicine and cellular longevity, 2(5), pp.270-278.

T'ai, H.R. and Cane, J.H., 2000. Pollen nutritional content and digestibility for animals. In Pollen and pollination (pp. 187-209). Springer, Vienna.

Sadasivam, S. and Manickam, A., 1992. Biochemical methods for agricultural sciences. Wiley eastern limited.

Stanciu, O.G., Mărghitaş, L.A., Dezmirean, D. and Campos, M.G., 2011. A comparison between the mineral content of flower and honeybee collected pollen of selected plant origin (Helianthus annuus L. and Salix sp.). Rom Biotechnol Lett, 16(4), pp.6291-6296.

Wakhle, D.M., 1981. Versatile pollen. Indian bee journal, 43(4), 114-117.

\section{How to cite this article:}

Dhananjay V. Shirsat, Snehal K. Kad and Dhananjay M. Wakhle. 2019. Solid State Fermentation of Bee-Collected Pollen. Int.J.Curr.Microbiol.App.Sci. 8(05): 1557-1563. doi: https://doi.org/10.20546/ijcmas.2019.805.180 